Humangenetik. Ein Kurzes Handbuch in fünf Bänden. Band IV. Edited by P. E. BECKER. (Pp. $\mathrm{xx}+556 ; 384$ figures. DM 174.) (Subscription price DM 139.20 if ordering all volumes.) Stuttgart: Georg Thieme. I964.

This, the second volume of this encyclopaedia to appear, is devoted to the sense organs. A section on the eye, contributed by D. Klein and A. Franceschetti of Geneva, runs to 207 pages which carry 250 illustrations, some in colour, and a bibliography of some 40 pages containing about 2,500 references. A section by $M$. Schwarz of Tübingen and the Editor deals with the ear, nose, and throat in 88 pages; this, too, with 62 illustrations and some 500 references, is well documented. The third and concluding section deals with the skin and its appendages and is contributed by $F$. Vogel of Heidelberg and H. Dorn of Berlin; it contains I60 pages, some 2,000 references and 92 illustrations.

Each of these three sections is adequate and well organized. The accounts they give are all the more useful as recent work is well covered, though this in many instances reduces the text to classified lists as very little information is available on the more recently recognized affections. In the section on the eye, the accounts of the classical affections are excellent, and the two concluding chapters on metabolic disorders and neuro-ophthalmological syndromes other than the typical lipoidoses are particularly helpful; one would have welcomed elsewhere in the text a clearer distinction between the disorders of a purely local type and those with associated generalized disturbances. In the section on the ear, both deaf-mutism and otosclerosis are well described, while the chapters on syndromes with congenital deafness and on voice and speech are most helpful. The section that breaks most new ground in classification is the one on the skin. A clear distinction is made between generalized dysplasias and dystrophies as opposed to localized disturbances of these types, and the mass of hereditary affections are clearly described in subdivisions of these major groupings. In addition, two relatively small sections on naevi and tumours take in what is not readily covered by this classification. Altogether this is a welcome volume.

A. $\mathbf{S}$.

The Matter of Mendelian Heredity. By K. R. LEwIS and B. JoHN. (Pp. 269; 53 figures + I5 plates + 37 tables; 40s.) London: J. and A. Churchill. I964.

This book is intended as a supplement to textbooks of general genetics for use in advanced school courses and at the undergraduate level. It is unorthodox in that the emphasis is on ideas rather than facts and its avowed object is to stimulate thought in student and teacher alike, rather than to encourage prodigious feats of memorization prior to examinations.

Medical and human genetics have unfortunately become divorced to some extent from the main stream of genetical knowledge. This is due partly to the different methodology imposed by the impossibility of experimental breeding in man and partly to differences of training in medicine and biology. Thus this book, which almost completely eschews the anthropocentric approach, will undoubtedly contain much that is new and stimulating to workers in medical genetics. There are eight chapters in all, covering, for example, such topics as the genetic system, evolution, and the relation of Mendelian heredity to mechanisms of reproduction. Two of the chapters deal with subjects of great practical importance, elementary statistical methods and the preparation of chromosomes for examination. The chemical basis of heredity is relegated to a brief chapter towards the end of the book since the authors feel that 'an understanding of the biological significance of the Mendelian discovery' is of more importance tham the knowledge of 'the detailed structure of a molecule - even the DNA molecule'. The last chapter is devoted to a short discussion of scientific method.

In pursuance of its aim of stimulating thought, this book is written in a style which is always forceful, often informal, and sometimes frankly jocular. There are many excellent, mostly original, figures and plates, many of which illustrate chromosomes and their behaviour. There is a relatively large number of trivial mistakes in spelling, which will doubtless be remedied in future editions.

G. R. FRASER

An Introduction to Medical Genetics, 3rd ed. By J. A. Fraser Roberts. (Pp. xiii +283 ; I2 I figures. 35s.) London: Oxford University Press. I963.

This is the third edition of the book that has established itself as the best introduction to genetics for present and future medical practioners. The book was original in that all the examples and illustrations were taken from medicine. It was lucid, exact and did not cover more than was appropriate for an introduction. These qualities have been preserved in the third edition. The startling new advances have been kept in perspective. Chromosome abnormalities, which have considerable clinical importance, have now been allotted one of the twelve chapters. The first chapter on chromo- 
somes and genes includes a brief account of the mechanism by which the deoxyribonucleic acid in the chromosomes controls the function of protein at the ribosomes. The main emphasis is still, rightly, on dominant, recessive and sex-linked conditions, the family patterns they show and how it may be established that a particular genetically determined disease is, for example, recessive rather than dominant or sex-linked.

Any criticisms can only be on matters of selection and emphasis. On grounds of practical usefulness there would be a case for shortening the section on linkage, and expanding the section on polygenic inheritance and the inheritance of common diseases and malformations.

A special feature of the book is the chapter on genetic prognosis. Dr. Roberts's experience of genetic counselling, especially for children's disorders, is unique and the principles he has established are now widely followed. These are: that it is not the doctor's task to advise parents whether or not they should have children, but to provide the information on which they can make up their own minds; that useful information may and should be given even where the exact genetic mechanism and the exact chances are uncertain; that the chances must be put into perspective for the parents by relating them to the approximately $I$ in 40 chance that any random pregnancy will result in a child with some minor abnormality or defect.

Several active workers in medical genetics entered the field as a result of reading the first edition of Dr. Roberts's book. The third edition will certainly stimulate more to do so.

C. O. Carter

Genetics for the Clinician, 2nd ed. By C. A. Clarke. Pp. 377 + xix; illustrated. 50s. Oxford: Blackwell. Scientific Publications. I964.

It is good to see a second edition of this book within two years. It is also good to see that it is no mere reprint. The text has grown by some 80 pages, mostly devoted to new sections. In the first edition, introductory theoretical material covered 88 pages, and very much the same amount of space was devoted to the genetics of the different systems. In the present edition three additional chapters on the respiratory tract, on neuro-psychiatry, and on renal disorders, increase the text on clinical aspects by half. There is also a new section on the construction of a pedigree, while the account on the chromosomes of man has been brought up to date. This thorough revision of the text should ensure its continued popularity.

A. $S$.

\section{INDEX TO VOLUME I}

ANDERs, J. M., see Joseph, M. C., et al.

Aortic stenosis, family study, 2

Ascites, chylous, in heterozygous ragged $(R a+)$ newborn mice, ro

Bird, G. W. G., Hasan, M. I., Malhotra, O. P., and LEHMANN, H.: Interaction of $\beta$-thalassaemia and hereditary persistence of foetal haemoglobin, 24

Bonham Carter, R. E., see Zoethout, H. E., et al.

BOOK REVIEWS

BECKer, P. E., editor: Humangenetik. Ein kurzes Handbuch in fünf Bänden, Band II. I964, 78: Band IV. I964, I52

Clarke, C. A.: Genetics for the clinician, 2nd ed., I964, I I I

CourT Brown, W. M., et al.: Abnormalities of the sex chromosome complement in man, 1964, 77

FranceschetTI, A., et al.: Les hérédo-dégénérescences chorio-rétiniennes (dégénérescences tapétorétiniennes), I963, 77

FrASER RoBerTS, J. A.: An introduction to medical genetics, 3rd ed., I963, I52

LEWIS, K. R., and JoHN, B.: The matter of Mendelian heredity, I964, I52
Blood groups in the Philippines, 107

Buckton, K. E., see Court Brown, W. M., et al.

Carter, C. O., see Zoethout, H. E., et al.

Chromatin, sex, see Sex chromatin

Chromosomes, sex, see Sex chromosomes

Clarke, G., Stevenson, A. C., Davies, P., and WilLIAMS, C. E.: A family apparently showing transmission of a translocation between chromosomes 3 and one of the 'X-6-12' or 'C' group, 27: Corrigenda, I53

Configurations, dermal ridge, 32

Court Brown, W. M., Mantle, D. J., Buckton, K. E., and Tough, I. M.: Fertility in an XY/XXY male married to a translocation heterozygote, 35

DaIkos, G. K., see HadjIDakis, S. G., et al.

Davies, P., see ClaRke, G., et al.

Deafness, profound childhood, review article, I 18

Diabetes in one monozygotic twin, idiocy in the other, 88

Down's syndrome in Nigerian children, 115

Dysostosis, cranio-facial, and malformation of feet, I I2

Dystrophy, muscular, see Muscular dystrophy 